David Rodin, 'The Myth of National Self-Defence', forthcoming in C. Fabre \& S. Lazar eds. 'The Morality of Defensive War', OUP.

\title{
4 \\ The Myth of National Self-Defence
}

\author{
David Rodin
}

\subsection{Chocolate}

On 2 February 2010 Kraft Foods succeeded in its hostile takeover bid of the UK confectionary company Cadbury. It had been a long struggle, made the more bitter by the very different cultures of the two firms. Kraft is a giant food, confectionary, and beverages conglomerate based in Northfields, Illinois. The company was originally created in the 1920's to execute a 'rollup' strategy in the US ice-cream industry-acquiring a large number of smaller firms and extracting savings by combining their operations and reducing staff. The company was an innovator in the processed cheese business, but Kraft's growth was always fuelled by an aggressive acquisitions strategy, taking over 55 firms in the 1920's alone. In 1988 Kraft was itself absorbed by the tobacco giant Philip Morris and was subsequently spun out in 2001 via the third largest IPO of all time. Kraft has always demonstrated a single-minded focus on financial returns and has a culture characterized by one analyst as 'mercenary'.

Cadbury could not have been more different. The company had had a continuous history of independence since its founding by John Cadbury in 1824. Cadbury was a Quaker, and together with his brother Benjamin, they forged the vision of a socially responsible company whose activities would benefit both employees and society at large. The very product line-coffee, tea, and drinking chocolate-was born out of a desire to provide less harmful alternatives to the pervasive Victorian tipples of gin and beer.

In the industrial England of Charles Dickens, Cadbury was a pioneer of employee rights and welfare. In the 1870's, when the company needed to expand, it purchased a large estate outside Birmingham and began a remarkable experiment in corporate social development. The new plant was to be a 'factory in a garden', and around it was built the model village of Bourneville. This was designed to be an ideal community embodying the Quaker values of human dignity, equality, and peace. Worker's cottages were constructed to an impressive modern standard around a pleasant central 
green and all had generous gardens. The village possessed remarkable educational, sports, and recreation facilities, all heavily subsidized or provided free by the company (although Quaker values dictated that the village have no public drinking establishments).

As the company grew during the twentieth century it remained committed to these founding values. Healthy industrial relations and environmental responsibility were hallmarks. When the company replaced some of the cocoa butter in their chocolate bars with palm oil as a result of consumer taste tests in 2009, they quickly responded to environmental criticism by reverting to cocoa butter by the end of the year. Employees were encouraged to see their relationship with the company as more than purely economic. Staff were offered time off to volunteer on community projects at the company's expense, and more than 80 per cent did so. ${ }^{1}$ Employees responded with a strong sense of loyalty. As one said: 'cut people open and they bleed purple', referring to the distinctive colour of the company's logo and chocolate wrappers. ${ }^{2}$

Many worried that Kraft's acquisition would spell the end of this unique collective identity. And so it proved. Within twenty-four hours of the takeover, Cadbury was effectively decapitated with the Chairman, Chief Executive, and Chief Finance Officer all departing. The headquarters were peremptorily moved from Britain to Kraft regional headquarters in Zurich. Despite providing assurances to the contrary, the historic manufacturing plant at Somerdale was closed with the loss of 400 jobs. Kraft's relentless focus on the bottom line was not compatible with Cadburys' principled and value-led culture.

As Kraft's hostile bid gathered momentum in 2009, there was considerable debate about whether and how Cadbury should be defended. The UK government expressed support, but ultimately declined to intervene. It determined that the continued independence of Cadbury did not outweigh other important principles, notably Britain's status as an open economy and the financial value that can be unlocked by allowing more efficient firms to take over less efficient ones. Cadbury was allowed to fall.

Although Cadbury PLC had not been owned by the Quaker Cadbury family since the 1960's, it never occurred to anyone, on either side of the debate, that the takeover could be resisted through force of arms. Whatever intrinsic or instrumental value resided in this self-determining community of nearly two centuries duration, its continued independence certainly did not justify the loss of even a single human life. This truth is so self-evident, that even stating it seems weird. Who could possibly believe otherwise?

\footnotetext{
${ }^{1}$ BBC, Cadbury: The Factory in the Garden, (2009) http://news.bbc.co.uk/2/hi/uk_news/england/ 8411696.stm (accessed 8 February 2012).

${ }^{2}$ Financial Times, Mergers and Acquisitions: A Bitter Taste (2011) http://www.ft.com/cms/s/o/o3 559624-8571-11eo-ae32-00144feabdco.html\#axzzılnPcm7A5 (accessed 8 February 2012).
} 


\subsection{War}

It is a foundational principle of just war theory and international law that states have the right to defend their sovereign independence through war. By any measure, this is a remarkable permission. It grants states the right to resist infringements of their territorial integrity and political independence (the two features together being constitutive of sovereignty) with lethal force. ${ }^{3}$ The scope of the permission is breathtaking. States are permitted to intentionally kill enemy combatants who are deemed to be responsible (though not necessarily culpably so) for an aggressive threat posed to their sovereignty. They are moreover permitted to unintentionally but foreseeably kill non-combatants who are not responsible in any way for the threat. It is important to understand that the latter is not simply a permission to inflict harm on the innocent, but is a permission to infringe their rights, since those killed collaterally in military action have not forfeited their right not to be killed. Both permissions to kill have been utilized by states on an epic, and in the twentieth century on an industrial, scale. Even more remarkable, as I will explore in this chapter, states are permitted to engage in war to defend their sovereignty even when doing so will predictably inflict greater loss of life and other basic rights on their own citizens compared with alternatives such as compromise, negotiation, or capitulation. ${ }^{4}$

Now recourse to defensive war is technically constrained by a requirement of proportionality. However mainstream philosophical, legal, and strategic practice has made it clear that the preservation of a state's sovereign independence from wrongful attack is attributed virtually infinite value in proportionality assessment. As a consequence, when the state's sovereignty is unjustly threatened with destruction (as distinct from lesser forms of infringement) considerations of proportionality are effectively suspended. It is worth recalling three well-known contexts from ethics, strategic practice, and law respectively, that brings this sharply into focus.

Michael Walzer famously argues that when a political community with its traditions, history, language, and culture is faced with destruction at the hands of an enemy, then it is in a situation of 'supreme emergency' in which the normal restrictions on permissible defence are suspended. ${ }^{5}$ Walzer specifically argues that when necessary to avert a supreme emergency a state is entitled to engage in acts of mass terrorism-that

\footnotetext{
${ }^{3}$ See the Charter of the United Nations, article 51: 'Nothing in the present Charter shall impair the inherent right of individual or collective self-defence if an armed attack occurs against a Member of the United Nations'.

${ }^{4}$ If wars of national defence are to be morally justified then these three distinct forms of harm (harm inflicted on enemy combatants, on non-combatants, and on the intended beneficiaries) must all be morally accounted for. Although the first two considerations have been extensively discussed, the third has been largely neglected. I discuss the harm that defensive acts inflict on beneficiaries under the heading internal proportionality' in 'The War Trap, Paradoxes and Dilemmas of Jus Termination', (forthcoming).

${ }_{5}^{5}$ Michael Walzer, Just and Unjust Wars: A Moral Argument with Historical Illustrations, 4th edn (New York: Basic Books, 2006), 253. Walzer limits supreme emergency to situations in which aggression poses an 'unusual and horrifying danger' (he is thinking here of Nazi aggression). This limitation is significant, and gives his position greater subtlety than the strategic or ICJ positions canvassed bellow.
} 
is to say the mass intentional killing of innocent civilians. This moral defence of terrorism (and Walzer, to his credit, is explicit and honest in his use of this terminology) is notorious in some circles since it violates the deep prohibition on the intentional killing of the innocent that has long been accepted by just war theory. But it is sufficiently mainstream to have been accepted by many leading theorists, most notably by John Rawls in the Laws-of Peoples. ${ }^{6}$

A commensurate attitude to the survival of the state was evident in a strategic doctrine that reached its height during the Cold War, but which still persists today. During that conflict, both superpowers explicitly affirmed their readiness to undertake a global nuclear war that would have destroyed both communities, as well as most life on earth, rather than suffer the unilateral destruction of their own sovereignty. US and Soviet defence planning, in other words, was premised on the readiness to undertake acts of war that would be not only terroristic, but also genocidal. Indeed, since a major nuclear confrontation would have destroyed all human communities we might more accurately call the strategy one of cosmogenocide (if a neologism will be here permitted).

One might think that the supreme emergency argument and the recent strategic practice of states are eccentricities or aberrations, but similar normative reasoning is employed in the most authoritative legal case on the ultimate scope of the defensive rights of states. In 1996 the International Court of Justice, at the request of the United Nations General Assembly, gave its advisory opinion on the Legality of the Threat or Use of Nuclear Weapons. The Court was clearly conflicted on the fundamental question of whether a state could be defended through the use of nuclear weapons, but ultimately it determined that there was no legal basis for denying the justification of using nuclear weapons in national self-defence: 'the Court cannot conclude definitively whether the threat or use of nuclear weapons would be lawful or unlawful in an extreme circumstance of self-defence, in which the very survival of a State would be at stake.' The Court thus endorsed (at the very least it pointedly failed to reject) the ascription of virtually limitless value to the continued existence of the sovereign state. ${ }^{8}$

How are we to account for these extraordinary permissions? We can do so only if there is some extraordinary and transcendent value inherent in, or associated with, the independence of the state. Michael Walzer has provided the most influential, and still by far the most plausible, account of the source of this value. He argues that the state

\footnotetext{
${ }^{6}$ John Rawls, The Law of Peoples (Cambridge, MA: Harvard University Press, 1999), 98-9.

7 International Court of Justice, Legality of the Threat or Use of Nuclear Weapons, Advisory Opinion of 8 July 1996, para. 105 (2)E.

${ }^{8}$ Precisely how to interpret the court's decision is controversial, since one could argue that the court did no more than pronounce non liquet - a situation of no applicable law. However, the UK Government's position is that the nuclear weapons case provides a positive legal basis for the permissibility of nuclear deterrence (see The Future of the United Kingdom's Nuclear Deterrent, FCO White Paper, December 2006, p.14.) Even to reach the more limited conclusion of non liquet in the context of the existing legal prohibition of intentional or disproportionate attacks on civilians requires ascribing an extraordinary status to the preservation of the survival of a state. I am grateful to Simon O'Connor for discussion of these issues.
} 
can defend itself through war because of the value of the community it represents: 'the survival and freedom of political communities-whose members share a way of life, developed by their ancestors, to be passed on to their children - are the highest values of international society.' This community is formed through 'a process of association and mutuality, the ongoing character of which the state claims to protect.'. 'The moral standing of any state depends en upon the reality of the common life it protects." This is a value collectively held and embodied in the shared life and liberty, the independent community which they have made.".

But here is the problem. Though it is not a state, Cadbury was an independent and self-determining community with recognizably similar characteristics to those that Walzer describes. It too was a community fashioned through a process of association and mutuality, whose members shared values and a way of life. Cadbury had a distinctive on-going character cherished by its members, passed on through generations, and maintained over several centuries. Yet when we look at what may be permissibly done in defence of this community's independence, we do not find a lesser form of the permission to use lethal force enjoyed by states, but rather no permission to use lethal force at all. Whereas the national community is attributed virtually unlimited rights to utilize violence and to infringe basic rights where necessary, other forms of community are attributed no rights of violent defence whatsoever. How can this be?

One immediate response is that lethal force is permissible only in defence of fundamentally important rights. We have the right to an independent self-determining state, but we do not typically believe that we have rights of comparable importance to participate in independent and self-determining non-state communities. ${ }^{13}$ But of course this just restates the problem. If the right to the independence of our state is grounded in the moral value of participating in a self-determining community, then why does participation in other forms of self-determining community not generate comparable rights?

There are three possible responses to this conundrum. First, we may accord to non-ate communities, such as Cadbury, rights to defensive force comparable to those possessed by states. Second, we may provide an account of relevant moral differences between state and non-state communities. Third, we may reject the right of national self-defence through war.

The first response is madness. No one in their right mind believes that communities like Cadbury can permissibly defend their independence with guns and nuclear

\footnotetext{
9 Walzer, Just and Unjust Wars, 254.

${ }^{10}$ Walzer, Just and Unjust Wars, 54.

${ }^{11}$ Walzer, Just and Unjust Wars, 54.

${ }_{12}$ Walzer, Just and Unjust Wars, 54 .

${ }^{13}$ Supporters of a right of national self-defence do, of course, often attribute the right to national communities that are not (yet) states. Such communities are typically conceived as having moral standing in part because they are potential states or proto-states. For simplicity, I will exclude such proto-state national communities from my usage of the term 'non-state' in the remainder of this chapter.
} 
weapons. The second response I will discuss at some length in the following section. The third response will be my conclusion. The right of national self-defence is a myth, unsupported by coherent moral reasoning. The case of Cadbury helps us to see this. Like many myths, however, the belief in national self-defence has exerted an extraordinary power over long periods of time. Until very recently it was doubted by no one, other than committed pacifists who typically reject all forms of violence. The reason for this myth's enduring power is that it has served an important function in the historical development of political order. A significant part of our argument, therefore, will have to be what J. L. Mackie called an 'error theory' of national self-defence: although I will not have space to develop this argument here, I believe we have good explanations for why this false moral doctrine has been accepted by so many people for so long. Equally there are hopeful signs that we are developing modes of political order that do not depend on this morally pernicious myth.

Before presenting the argument, let me first indicate the scope of the challenge. There are two basic strategies for justifying a right of national self-defence. First, one might seek to show that the state itself possesses a right of defence analogous to the individual right of self-defence-the analogical strategy. Second, one might seek to show that national self-defence is the coordinated exercise of individual rights of defence-the reductive strategy. ${ }^{14}$ Something like the Walzerian account of the value of the state is clearly a prerequisite of the analogical strategy. In the last decade, however, all the philosophical action has been within the reductive strategy. ${ }^{15}$ It may seem that because its focus is on the rights and status of individuals, the reductive approach does not require an account of the value of the state community. But this is a mistake. In section 4.4 I will argue that the reductionist strategy can only succeed if the state possesses a value comparable to that accorded within the Walzerian conception. I will demonstrate this through an extended discussion of the complex phenomenon of conditional threats.

\subsection{States and Other Communities}

To determine whether there is something morally distinctive about the survival of a state (or in the reductionist mode, of the right of individual citizens to the survival of their state), we must first understand the moral nature of the community that underlies it. That turns out to be a difficult The state is clearly not unitary anatural kind like an organism (although this was once an influential view). The

\footnotetext{
${ }^{14}$ David Rodin, War and Self-Defense (Oxford: Oxford University Press, 2002), ch. 6. As I there explain, one can be a reductivist or pursue and analogical account with respect to the subject, object, or ends of defensive action. The contrast between a 'reductivist' or 'analogical' approach is therefore something of a simplification.

${ }^{15}$ See in particular the work of Jeff McMahan, 'The Ethics of Killing in War', Ethics, 114/4 (2004), 693-733; Killing in War (Oxford: Oxford University Press, 2009.); Thomas Hurka, 'Proportionality in the Morality of War', Philosophy and Public Affairs, 33/1 (2004), 34-65; Cécile Fabre, Cosmopolitan War (Oxford: Oxford University Press, 2012).
} 
state is associated in various ways with a range of more or less empirically respectable social phenomena such as nationhood, ethnicity, blood relations, and linguistic and religious identity. The problem is that none of them align in appropriate ways with statehood. There are as many multi-national states (such as the United Kingdom) as there are stateless nations (such as the Kurds or the Jews for much of their history). Many post-colonial states in Africa and Asia contain numerous distinct ethnic groups. Immigrant states such as the United States have no unifying blood relation between citizens. States such as Switzerland and Canada contain multiple linguistic communities, and numerous states contain multiple religious communities. Of course, it is true that the distinctive character of many states is given by an overlapping matrix of these different social identities within their population. But that is true also for many non-state groups such as corporations, international organizations, and country clubs.

Nor is it the case that the state is exercising the defensive rights of social groups such as national or ethnic communities on their behalf. If a man is defending the lives of three people from an unjust attack, he will be entitled to inflict three times as much unintended harm on innocent bystanders as a man who is defending only one life. But the United Kingdom is not entitled to inflict three times as much collateral harm in a defensive war than is France, even though the United Kingdom contains within its border the three nations of England, Scotland, and Wales (as well as a portion of the Irish nation).$^{16}$

If, as Walzer argues, the state has the right to defend itself because it is associated with a morally important community, then the community in question can only be the community formed through the collective experience of participating in the state itself. This may seem an unpromising starting point, but in fact the shared experience of statehood is socially powerful because the state itself is uniquely powerful. No other entity on earth possesses powers comparable to the modern state. My state possesses the legal power to deprive me of my property, my liberty, and my life; it can conscript me, or quarantine me with carriers of a deadly disease. More positively, the state is also a significant locus of social justice. The state (and only the state) can coercively redistribute wealth in accordance with a conception of justice, provide universal health care and education, and administer effective criminal justice. Because of this, states typically form the most important context for collective decision making (i.e. politics) in modern societies. ${ }^{17}$ It is not surprising that the community defined by shared membership of a state comes to have great significance for us.

The state is powerful and pervasive and this gives it great moral salience. But the state is also distant. Corporations like Cadbury are less powerful, but our relationship

\footnotetext{
${ }^{16}$ Similar problems arise for the hypothesis that states exercise the defensive rights of their citizens on their behalf. See Seth Lazar, chapter 2 in this volume.

${ }_{17}$ This context should not be exaggerated. John McDermot writing in the Financial Times argues that the modern state is essentially 'a health and welfare insurance scheme backed by a military'. This overstates the case, but the deflationary point is well taken. (John McDermott, 'Britain is no Country for Young Men', Financial Times, 16 March 2012)
} 
with the companies that employ us are much more intimate. Even in liberal democratic societies, where the state deeply penetrates society through its provision of goods and services, and where we enjoy rights of democratic participation, interaction with the state and its officials are relatively rare and remote. Many people will interact with the justice or welfare systems only a few times in their life. They may vote once every few years, and they may interact with the health system (in states where this is public) a few times in a year. They may have contact with other sundry officials perhaps a few times in a month.

In contrast, most people spend one third of their adult waking lives in their work environment. During this time we both represent our employer and interact constantly with its officers and employees. Often our most important friendships and social relations are forged at work. Psychological research tells us that our job is one of the strongest factors in the construction of our personal identity. That is why losing one's job is one of the most traumatic experiences a person can suffer, comparable in emotional stress to the experience of divorce, and substantially worse than suffering the death of a close friend..$^{18}$

The community defined by shared membership in a state is clearly different to non-state communities such as those defined by corporations. These different communities create social value and collective salience in different ways. The state is more powerful but less intimate. Both forms of community are clearly important, though in very different ways. Certainly there is nothing to suggest that the survival of one form of community should be accorded near infinite value, whereas the survival of the other next to none in determining permissible defensive action and legal protection for its independence.

One might respond that this is not how most people see it, and that fact in itself is morally relevant. No one is prepared to kill or to die for the survival of the firm they work for, but throughout history people have been prepared to kill and die for their state. It is a brute fact that allegiance to king and country is held by most people to be profoundly more important than any other social allegiance.

But this is to confuse belief with fact. In some parts of the world it is commonly believed to be permissible or obligatory to kill a daughter or sister who has sullied the 'honour' of her family by engaging in sexual intercourse (or perhaps by being raped) out of wedlock. For many centuries in India brides believed that they had an obligation to immolate themselves on the funeral pyres of their husbands. Believing that something is worth killing or dying for does not make it so. This is as true for the collective value judgements of societies as it is for the judgements of individuals.

Moreover, it is unclear what the direction of causality of these beliefs is. Do people believe it is permissible to kill and die for the state because the state has transcendent value? Or do they believe that the state has transcendent value because so many

${ }^{18}$ See Thomas H. Holmes and Richard H. Rahe, 'The Social Readjustment Rating Scale', Journal of Psychosomatic Research, 11/2 (1967), 213-18. 
people have killed and died for it? It is no coincidence that throughout the world states utilize the memory of past wars, and the preparation for future war, to enhance their perceived legitimacy. This works because of the psychological dissonance that would result from denying the overriding moral importance of the state. How could one believe that all that effort, all the horror and massacre, the loss of brothers and fathers and sons, was for an entity that on close inspection shares moral characteristics with the makers of a popular chocolate bar?

There are other differences between the Kraft-Cadbury case and defensive war. One of the most obvious is that Kraft's takeover of Cadbury was entirely legal, and therefore not (legally) unjustified. Defensive rights are only possessed against unjust threats of harm.

This obviously begs the question of whether it is morally right for the law to permit the takeover of independent companies like Cadbury. If, as the Walzerian argument suggests, there is a profound moral value in the continued existence of long-standing and distinctive independent communities, then perhaps the law should not permit hostile takeovers. Furthermore, we can easily alter the case to a hypothetical situation in which the takeover was unlawful: suppose Kraft's takeover bid was fraudulent, but conducted in such a clever manner that it could only be prevented by killing one of the firm's officers? Most would feel that it would not be permissible to kill in order to prevent a criminally fraudulent takeover of Cadbury, just as it would not be justifiable to kill in order to prevent a lawful takeover.

But fraud is a non-violent crime. Perhaps states have the right to kill in self-defence because their independence in threatened through action that is not only unjust, but also violent. This suggestion doesn't take us very far. Suppose Kraft's takeover bid was conducted through fraudulent action that was not only criminal, but also violent: breaking into the offices of Cadbury's accountants to falsify documents and killing a security guard in the process. It would certainly be permissible to use force to prevent the unjust killing of the guard. But the fact that the violent break-in was an unjust threat to the continued independence of the Cadbury Corporation adds little or nothing to the permission to use defensive force against the perpetrators (or to the permission to inflict foreseen but unintended harm on innocent bystanders). It is the life of the guard, not the independence of Cadbury that is properly defended with force in this case.

However, it might seem that this analysis again misses a morally distinctive feature of aggressive war. Aggression contains an implicit threat to utilize further lethal violence if resistance is met and demands not complied with. The morality of conditional threats is highly complex and will be discussed in the following section. To anticipate the argument I will there make, it is in fact not true that there is a general permission to respond to conditional lethal threats with lethal violence. Moreover, the fact that an aggressor is deploying a conditional threat of lethal force can provide strong (and in some cases overriding) reasons not to respond to his threat with any force at all. 
A further difference between the Cadbury case and some paradigm cases of national self-defence is that Cadbury was not a democracy. Cadbury was a self-determining community in the sense that it was independent, that is to say, not subject to external control. But ultimate governance of the corporation lay with the Board of Directors, who were not accountable to the employees of Cadbury, but rather to the owners (in the early years the Cadbury family and, subsequent to its public listing, the shareholders). In this sense Cadbury was more like a benign dictatorship, comparable to Rawls' conception of a decent consultation hierarchy. ${ }^{19}$

If the right of defence through war is limited to communities that are self-determining in the stronger sense that they are democratic, then the troubling case of Cadbury can be excluded. Of course this would require us to bite a substantial bullet. Poland was not a democracy when it was invaded by Germany, and Kuwait was not a democracy when it was invaded by Iraq, yet these are considered to be paradigm cases of justification for defensive war. Both Walzer and Rawls, supposed that decent hierarchical peoples possess the right of self-defence. International law grants the inherent right of self-defence to all states, a right only circumscribed by the recent doctrine of Responsibility to Protect that establishes of a right to intervene in states that are engaged in mass atrocities against their own citizens. Moreover, many people believe that the 2003 invasion of Iraq did not possess a just cause, though Iraq was not a democracy and an explicit goal of the invasion was to bring democracy to Iraq (a goal that was at least in part accomplished).

But perhaps just war theory ought to be revised so that only democratic states possess the right to defend themselves through war. This would be a momentous revision indeed, and the politics of its implementation do not bear thinking about. But it is conceivable that in the future we will deny the right of self-defence to states that violate the democratic rights of their citizens in the same way that we have progressively denied the right of self-defence to states that systematically violate the basic human rights of their citizens.

Unfortunately, even a revised just war theory that excluded non-democratic entities from enjoying the right of self-defence would not help with the present conundrum. Consider 'mutual corporations' that are wholly owned by their employees, and governed democratically by them. One such company is the John Lewis Partnership, a UK retailer with a tradition of social responsibility almost as long and distinguished as Cadbury's. Yet I doubt that anyone would countenance the violent defence of John Lewis from an unjust threat to its independence. It is doubtful, even, whether John Lewis would be ascribed any greater defensive rights than its less democratic peer, Cadbury. The right to democratic participation in a self-determining community does not play a decisive role in establishing rights to collective defence through war.

\footnotetext{
${ }^{19}$ John Rawls, The Law of Peoples (Cambridge, MA: Harvard University Press, 1999), 75ff.
} 
A final hypothesis is that states possess the right of self-defence whereas non-state communities do not because the state is the guarantor of other communities. The value of all non-state communities is combined in the state because it is the state that protects and makes possible these communities. This proposal suffers from the problem canvassed above. If the state possesses value because of the communities that exist within its territory, then we would expect that states with rich ecosystems of local communities would enjoy greater defensive rights than states with sparser communal activity. They do not.

Furthermore, the case of Cadbury shows that the supposition that states protect the communities within their borders is often false. The UK government was indifferent to the fate of Cadbury. It had the legal competence to halt the foreign takeover of the firm without the shedding of so much as a drop of blood, but declined to do so. Cadbury was fortunate that the UK government was only indifferent. Many states actively persecute or seek to eliminate communities within their borders as the Chinese state does to the Falun Gong movement.

None of the above is intended to trivialize the moral standing of state communities. As I have suggested, moderate communitarians like Michael Walzer are right that the enduring community produced by the shared experience of living within a state can have great moral importance. But they are wrong if they hold that the state community is unique in this respect. Many other forms of collective, including some commercial organizations, have can have a similar status. These communities differ from states along a number of dimensions, but there is no reason to believe they cannot sometimes have a comparable value. What the comparison teaches us is that value inherent in such communities is not sufficient to justify defence with lethal force.

\subsection{Conditional Threats}

The Walzerian approach to the value of state communities clearly has significant problems. But how does this effect contemporary reductivist approaches to the ethics of war? This is how the reductive strategy is characterized by its greatest contemporary advocate, Jeff McMahan:

'First imagine a case in which a person uses violence in self-defense; then imagine a case in which two people engage in self-defense against a threat they jointly face. Continue to imagine further cases in which increasing numbers of people act with increasing coordination to defend both themselves and each other against a common threat, or a range of threats they face together. What you are imagining is a spectrum of cases that begins with acts of individual self-defense and, as the threats become more complex and extensive, the threatened individuals more numerous, and their defensive action more integrated, eventually reaches cases involving a scale of violence that is constitutive of war.'2

\footnotetext{
${ }^{20}$ Jeff McMahan, 'War as Self-Defense', Ethics and International Affairs, 18/1 (2004), 75-80, 75.
} 
Now McMahan is correct to admit the possibility of large-scale and socially coordinated violence consisting entirely of individual actions that are morally justified on grounds of self or other-defence. Instances of humanitarian intervention have satisfied (or could potentially satisfy) this condition. But two questions are key: First, is McMahan correct to describe such coordinated acts of individually justified self-defence as war? Second, can the possibility of coordinated individual self-defence be used to ground a right of national self-defence congruent with mainstream just war theory and international law? I believe that the answer to both questions is no.

The first issue I have discussed extensively elsewhere..$^{21}$ In ordered to answer the second question, consider the distinction between two different forms of aggression. The first is what we might call 'genocidal aggression'. This is aggression that threatens the vital interests of all, or a significant proportion, of a group of people. By 'vital interests' I will mean those centrally important interests, the unjust threat to which can justify lethal force in a domestic context of self-defence. These are in broad terms: threat to life, substantial threat to bodily integrity (including loss of limb, torture, and rape), profound attacks on liberty such as slavery, and permanent or long-standing displacement from one's home..$^{22}$ Acts of genocide are clearly the paradigm of this form of threat, but I want to use the term 'genocidal aggression' in a looser way to encompass mass threats to vital interests that do not conform to the strict legal definition of genocide (that is to say acts committed with 'the intent to destroy, in whole or in part, a national, ethnic-al, racial, or religious group'). ${ }^{23}$ This may be because the group under threat does not possess one of the particular identities specified, or because the attackers lack the specific intent of the crime of genocide. For example, the attackers may be pirates or raiders who have no interest in destroying the group in whole or in part, but whose actions do in fact pose such a threat. Because a functioning state is a prerequisite for the secure enjoyment of almost all rights and vital interests in the modern world, any aggressive act that either intentionally or foreseeably deprives a group of access to an effective state (in other words reduces them to a state of anarchy) would constitute genocidal aggression as I am using the term. The picture that McMahan provides of large scale and coordinated exercise of individual acts of self-defence is plausible in the context of resistance to genocidal aggression.

\footnotetext{
${ }^{21}$ McMahan follows contemporary social science in conceiving of war as collective violence that reaches a certain level of scale and coordination. But for the purposes of moral assessment, an older tradition of thought, originating in the work of Carl von Clausewitz, is more pertinent. Within this tradition, the distinguishing feature of war is its status as a political act. Coordinated acts of individual self-defence can have the scale and intensity of war but they lack this fundamental political character. For this reason they should not properly be conceived as acts of war. I develop this argument in 'Rethinking Responsibility to Protect: The Case for Human Sovereignty', in Donald Scheid (ed.), Humanitarian Military Intervention (Cambridge: Cambridge University Press, forthcoming 2014.)

${ }^{22}$ This account of 'vital interests' and of 'political aggression' introduced bellow broadly coincides with Lazar's usage in this volume.

${ }^{23}$ The Convention on the Prevention and Punishment of the Crime of Genocide, article 2.
} 
Contrast genocidal aggression, with what we might call 'political aggression'. While genocidal aggression directly targets the vital rights and interests of a significant proportion of a community, political aggression is primarily directed towards obtaining a political or material advantage for the attackers. This may be achieved by seizing land, establishing control over resources, or by replacing an existing political order with one that is more congenial to it. It is important to realize that while political aggression may destroy the existing state through absorbing or assimilating the territory to another state, it does not leave the population stateless (if it did it would count as genocidal aggression on my usage). Although genocidal aggression sadly does occur, it is clear that political aggression is by far the most important form of aggression when it comes to rights of national self-defence (acts of genocide are most commonly perpetrated by states against elements of their own population).

Political aggressors are, of course, quite prepared to threaten the vital interests of those in the aggressed group if resistance is met, but this is not their primary purpose. The threat they pose to vital interests within the invaded state is a 'conditional threat'. A conditional threat is one that has the structure of the old highwayman's cry: 'your money or your life!' Analytically it consists in two distinct components-a direct threat to a lesser interest (the money) and a contingent threat to a greater interest (the life). The antecedent of the contingent threat is resisting the direct threat to the lesser interest.

The fact that political aggression is carried out through conditional threats plays a decisive role in determining the permissibility of defensive war-but not in the way that one might suppose. The presence of a conditional threat to vital interests provides a substantial moral reason not to engage in defence against the direct threat. This is at odds with how conditional threats have historically been treated. John Locke famously argued that there is a right to resist with lethal force someone who makes a conditional threat on your life, even if the directly threatened interest is not sufficient to merit lethal defence. ${ }^{24}$ This position has been endorsed by a number of contemporary scholars. ${ }^{25}$

Seth Lazar has produced an elegant and devastating critique of this position. ${ }^{26} \mathrm{He}$ points out that the Lockean permission to preventively kill conditional aggressors is viciously circular. The fact that a conditional aggressor will threaten the defender's life at $\mathrm{T}_{2}$ cannot be used by the defender in his proportionality calculation at $\mathrm{T}_{\mathrm{o}}$ to justify defensive force at $\mathrm{T}_{1}$, unless the defensive force at $\mathrm{T}_{1}$ is independently justified. For example, if a victim responds to the direct threat posed by a mugger with grossly disproportionate force (for example, by tossing a grenade that would also kill a number of nearby children), then the fact that the mugger would respond to the defender's

${ }^{24}$ John Locke, Two Treatises of Government, (Cambridge, Cambridge University Press, 1960), Book II, Chap. III, p. 279-8o. See also Jeff McMahan, 'Innocence, Self-Defense and Killing in War', The Journal of Political Philosophy, 2/3 (1994), 193-221, 196.

${ }_{25}$ See Fabre, chapter 5 in this volume.

${ }^{26}$ Seth Lazar, chapter 2 in this volume. 
disproportionate action with lethal force at $\mathrm{T}_{2}$ cannot be used by the defender to justify killing the mugger preventively.

One might suppose, however, that the practical implications of this critique are limited. This is because of a seemingly plausibly supposition (which is accepted also by Lazar) that the justification of resisting the direct threat to the lesser interest at $\mathrm{T}_{1}$ can be established independently of the contingent threat to the greater interest at $\mathrm{T}_{2}$. If that is so, then a defender could still resist political aggression through a war of self-defence by staggering his response in two stages. In the first stage the defender would undertake measures that are designed to be proportionate to the non-lethal direct threat of the political aggressors (for example, the defender might barricade the path of invading troops). If the aggressor responded to these defensive measures with lethal force, then the defender would be justified in responding in turn with lethal force. This would impose some operational and tactical constraints on a defender, but would leave his right to engage in defensive war largely undisturbed.

However, this supposition is not correct. The morality of resisting the direct threat component of a conditional threat cannot be determined independently of the contingent threat component. Specifically, when a direct threat to a lesser interest is accompanied by a contingent threat to a vital interest, this provides a moral reason not to defend the lesser interest, even if using the same level of defensive force would have been proportional, absent the contingent threat. Some actions to defend the political interests of members of a community that would be permissible against a straightforward direct threat (for example, non-violently barricading the way against an aggressor), may become impermissible when the direct threat to those political interests is backed up by a contingent threat to life.

This counterintuitive conclusion follows from the fact that the permissibility of engaging in defensive action is in part determined by the foreseeable consequences that the defensive action will produce. Defensive action is impermissible when it foreseeably produces harmful effects that are disproportionate to the good one is seeking to achieve. In a conditional threat situation, the aggressor will inflict additional (lethal) harms as a consequence of the defender's action to resist the direct threat. These additional harmful consequences of defensive action must be factored into the proportionality calculation when determining the permissibility of defending against the direct threat.

The conditional harms inflicted by a political aggressor are obviously a foreseeable consequence of undertaking defensive action. However, not all foreseeable harms count for the purposes of proportionality in the same way. The foreseeable harmful effects of action that results from the wrongful intervening agency of others may be discounted for the purposes of both proportionality and the attribution of moral responsibility, compared with harmful effects that do not result from the wrongful agency of others. ${ }^{27}$ However, although harms arising from wrongful intervening

\footnotetext{
${ }^{27}$ See Thomas Hurka, 'Proportionality in the Morality of War', Philosophy and Public Affairs, 33/1 (2004), $34-65,47 \mathrm{ff}$.
} 
agency are discounted, they are not discounted to zero; such harms remain relevant to judgements about proportionality and responsibility.

Both considerations are evident in the following example. Suppose you know a violent and unstable individual who has a morbid obsession with his receding hair-line. You have good reason to believe that referring to his thinning hair will cause him to fly into a murderous rage, and that, moreover, he has an automatic weapon concealed in his desk. You teasingly draw attention to his bald spot and as a consequence he pulls out his gun and kills several innocent people. What is your responsibility for these deaths? Clearly you do not have the same responsibility as the gunman. His wrongful intervening action diminishes your responsibility for the deaths. ${ }^{28}$ But it is equally clear that, though referring to someone's thinning hair is not normally impermissible, there are strong, indeed decisive, moral reasons not to do so in this context. These reasons ground some attribution of responsibility to you for the deaths, and are probably also sufficient to establish culpability based on the extreme recklessness of your action.

The conditional harms posed by an aggressor have the same status. They provide some moral reason not to engage in defensive acts against a direct threat that would have been permissible in the absence of the contingent threat. However, the weight of the reason they provide is mitigated by the fact that the harms result from the wrongful intervening action of the aggressor. To use Hurka's metaphor, there is a thumb pressed down on one side of the proportionality scale minimizing the restrictive effect of these foreseeable harms on the permissibility of engaging in defensive action.

However, there is an additional factor. The victims of the aggressor's conditional threats are typically people who are bound to us by relationships of loyalty, community and kinship. The additional people who will be killed by the conditional aggressor if we defend against the direct threat are 'our people'; they may be our comrades in arms, our family members, our neighbours. These are people to whom we owe a duty of care. These duties of care affect the way that harmful consequences of action affect moral permissibility.

Let us consider first one way in which duties of care do not affect moral permissibility, and then one way in which they do. Suppose that an aggressor is threatening the life of two innocent children and that the only way to avert the wrongful attack is by intentionally using a third innocent child in a way that will cause his death. Clearly, it would be impermissible intentionally to kill the third child in order to save the two. This remains the case even if the two threatened children were the defendant's own son and daughter. Duties of care to the victims of aggression do not augment the permission to intentionally kill innocent persons in the course of defensive action.

\footnotetext{
${ }^{28}$ Hurka canvasses, but remains agnostic about, a considerably more restrictive view according to which harms that result from wrongful intervening action are only discounted if the harms are inflicted on the intervening actor himself. Hurka, 'Proportionality in the Morality of War', 49-50.
} 
Consider now a case in which an aggressor threatens the life of five children, and the attack can be averted only through defensive action which has the foreseen but unintended effect of causing the death of a sixth child who is an innocent bystander. Suppose, plausibly, that undertaking the defensive action is not only permissible, but also weakly obligatory in the sense that someone who had the opportunity to intervene but did not do so would merit condemnation. Suppose now that the sixth child who would be foreseeably killed by the defensive action was the defender's own son. This fact is clearly relevant to the morality of his engaging in the defensive action. Because the defendant bears a duty of care to his son, he is not obligated to perform the defensive acts that will foreseeably bring about his death. Moreover he is arguably obligated not to engage in the defensive acts. Duties of care owed to those who would be foreseeably, but unintentionally, harmed by defensive action increase the moral reasons against performing those defensive acts.

Why do duties of care have differing effects in these two contexts? The reason has to do with the difference between the obligation not to harm and the obligation to assist. In the first case the duty of care is being pitted against the obligation to not intentionally harm non-liable persons. The obligation to not intentionally inflict serious harm on those not liable to it is extremely strong, and overrides even the strongest duties of care and of assistance. In the second case the duty of care is pitted against the duty to assist the five children. The duty to assist is weaker than the duty not to harm, in the sense that it can be overridden by special relationships and duties of care. Just as we are permitted to provide goods and assistance to those who are specially related to us in preference to strangers who may have greater need, so also we are permitted not to harm those specially related to us even if this is necessary to avert greater harm to strangers.

Let us take stock of the argument so far. When assessing the permissibility of defence against the direct portion of a conditional threat, the likely infliction of the contingent portion of the threat counts against defensive action in the proportionality calculation. While there is one thumb pressing down on the permissive side of the proportionality calculation because the contingent harms come about through the wrongful intervening action of the aggressor, there is another thumb pressing down on the restrictive side of the proportionality calculation because those who would suffer the contingent harm are in a special relationship with the defender and are owed duties of care by the him. What might the net effect of these two countervailing normative forces be?

Think of how they play out in the following analogy: Suppose that an armed villain invades and occupies your home without justification. He lives in your house, eats your food, and makes you and your family do all the work. He is a conditional aggressor who wants to enjoy the spoils of your house, not fight. He makes it clear that he will not use violence unless resistance is met. There is no end in sight. You could defeat the invader through force, but a likely consequence is that one of your children would be killed, either as side-effect of the struggle, or as a reprisal meted out by the aggressor as 
a consequence of resistance. Would it be permissible to engage in defensive action that caused the death of your child?

I suspect that most people feel that it would not be right to resist, unless and until the situation evolved in such a way that the aggressor was likely to kill a member of your family whatever you did-in other words, only at the point at which the threat to life ceased to be contingent and became direct. As bad as the situation is, averting it does not outweigh the value of a child's life-especially since this child is your child and you owe a profound duty of care to him. This example suggests that in the tension between the permissive effect of wrongful intervening action and the restrictive effects of special duties, it is the special duties that have priority. ${ }^{29}$

Conditional lethal threats provide no automatic justification of preventive resistance with lethal force (contra Locke). Moreover, it may be the case that it is impermissible to resist even the direct component of a conditional threat through defensive measures that in non-conditional contexts would be entirely permissible if the result is the death of innocent persons who would not otherwise die..$^{30}$

Could the restrictive effect of duties of care be neutralized through a process of consent? As I mentioned in the introduction, the dominant experience of war for most individuals is not one of the assertion of self-interest (as we would expect if war were genuinely a form of collective self-defence against joint threats), but one of solidarity and sacrifice. Perhaps when faced with a political aggressor the members of a community implicitly waive their rights to care. By doing so they may morally empower their fellow citizens to engage in defensive acts that will expose them to greater risk of death.

There are familiar problems with this form of proposal: how would we know that citizens had consented to waive their rights to care? What about children and others unable to consent? But there is a deeper problem also. Duties of care are different from most other duties in that they are not only the correlates of rights. For example, the duty of care that I owe to my son is not grounded only in the care that he has the right to expect from me as a father. It is also grounded in the love and affection that I feel for him. He may waive his rights to care (assuming the appropriate competence to do so), but he cannot so easily waive the duty that arises out of the paternal bond that I have with him.

It might be argued that there is an important consideration that has been left out of this argument, namely the consideration of deterrence. If you don't resist the aggressor you may preserve the life of your child on this occasion, but you will invite repeated

\footnotetext{
${ }^{29}$ It might be objected that the example overstates the likely costs of resisting conditional aggression, since it is not plausibly the case that all families would suffer the death of a child as the result of a decision to resist political aggression (though some families certainly will suffer this fate). That is certainly true, but the example also overstates the direct costs of political aggression. Few, if any families, under a political aggressor would suffer the harms of being reduced to servitude to an armed aggressor living in their own home. No analogy is perfect, but the example, as constructed, plausibly conveys the balance of direct and contingent costs arising from typical acts of political aggression.

${ }^{30}$ Note this is a more restrictive analysis than the one I gave in War and Self-Defense, 132-7.
} 
attacks in the future. Resisting aggression involves immediate costs but it will make you more secure in the long run. As Rudyard Kipling had it:

... we've proved it again and again,

That if once you have paid him the Dane-geld

You never get rid of the Dane. ${ }^{31}$

The foreseeable death of those to whom you owe a duty of care presses down on the restrictive side of the proportionality calculation for resisting political aggression, but the deterrence effect presses down on the permissive side. Moreover, there may be some generalization of the deterrence effect, so that its benefits will be enjoyed not only by your community, but by others also.

What is the strength of this deterrence consideration? Two factors weaken the impact of deterrence on proportionality. First, the goods brought about by deterrence are temporally distant-they lie in the future, and future goods are discounted with respect to present value. This is for two reasons. First monetary and many material goods have a lower net present value in the future than they do today. A thousand dollars a year from now is worth less than a thousand dollars today. Second, in the intervening time we may find other, less costly, ways of achieving the same good. Deterrence effects that must be purchased today through the death of a child, may be accessible at a later date by less costly means-for example engaging a security company. Thus, there may be option value in deferring the deterrence of aggression to a point in the future.

Deterrence effects are also discounted because they are extraordinarily uncertain. What is the deterrent efficacy of violently resisting aggression? Despite Kipling's assurances that it has been 'proved again and again' there is in fact scant empirical support. We do, however, know what a well-designed deterrence system looks like in the domestic context-and it looks nothing like national self-defence against political aggression. A functional deterrence system, like the modern criminal justice system aspires to the following characteristics: (1) sanctions are reliably and consistently applied in almost instances of breach, (2) sanctions are not applied by the victim of the breach, but by a public authority which has highly developed epistemic capabilities to determine whether a breach has taken place, and is impartial between disputing parties, and (3) the authority which applies sanctions has a monopoly on the legitimate use of force, and a virtual monopoly on actual use of force within the society. Acts of national self-defence typically have none of these characteristics. They are a form of 'self-help' in which states seek to vindicate their own rights. States lack impartiality as they act in their own case, and have far from ideal epistemic capabilities. The sanction of resistance is uncertainly applied, as only strong states have a realistic prospect of resisting aggression. Indeed because just war theory insists on a reasonable prospect of success as a precondition of engaging in defensive action, those in most need of protection (the

\footnotetext{
${ }^{31}$ Rudyard Kipling, 'Dane-Geld'.
} 
weak) are denied recourse at the level of moral theory. There is no global monopoly on the use of force.

The international deterrence system is so dysfunctional that it also has the capacity to generate significant moral externality costs that work counter to deterrence. Suppose a state succeeds in resisting a direct threat against its political sovereignty. This may deter adversaries from engaging in similar acts of aggression in the future. Or it may create incentives for adversaries to obtain a decisive military advantage (for example, through alliance), and to engage in genocidal rather than political aggression in future. Even if defensive acts deter future aggression against that state, it may create an incentive for aggressors to attack other weaker states, thus future threats may simply be deferred to others rather than deterred.

Although deterrence has played an important role in strategic thought, these considerations suggest that its role in moral reasoning should be negligible-at least until such time that it is placed on a more secure empirical and theoretical footing.

Political aggression and genocidal aggression have a fundamentally different moral structure. Resistance to political aggression will often produce greater loss to vital interests among individuals within the defended group, compared with engaging in no defence at all. That is a striking observation, but it's possibility follows directly from the nature of conditional threats - a conditional threat just is a situation in which the threat of greater harm is a consequence of resisting lesser harm.

This has been obscured because most discussion of conditional threats has focused on individual self-defence in which confrontation is a one-off event. An individual defender in a conditional threat situation can sometimes forestall the contingent threat by killing or disabling the aggressor in a single decisive blow. This is rarely the case in war. Aggressive and defensive war consists in iterated individual confrontations that occur over a period of time. The extended temporal dimension enables a political aggressor to inflict substantial contingent harm on the defender even if the defender is ultimately victorious. Moreover, the threat context at the outset of war does not remain stable during the course of war. Wars are notoriously prone to escalation, as each side commits more resources to the conflict in order to avoid defeat. Thus the intended beneficiaries of defensive action may end up suffering harms that are greater even than the contingent harm implicit within the initial conditional threat.

There is, indeed, no obvious precedent of morally justified acts of individual self-defence that have the typical structure of war against political aggression-acts of self- or other-defence that have the foreseeable likely consequence of generating greater harm to the vital interests of the very people the defensive action is intended to benefit. Expressed in this way, defensive war against political aggression is often straightforwardly self-defeating and hence morally irrational.

This point should be obvious, since the phenomenology of war is quite at odds with that of personal self-defence. Self-defence is typically an act of permissible self-interest. No one needs to be induced to engage in genuine acts of self-defence against a threat they jointly or individually face. But states use their most coercive powers to induce 
citizens to engage in military service: they pay soldiers a salary, give them the public adulation of heroic honour, and retain the power to conscript them on penalty of imprisonment or death..$^{32}$ For most participants, the dominant experience of war is not the assertion of personal self-interest, but of personal sacrifice for something other (and presumably greater) than the self.

There is thus a gap-a value deficit-at the heart of the reductivist account. This gap can only be filled if there is some other value, beyond the vital interests of citizens, that plays a decisive role in national self-defence. This value must be so significant that it outweighs not only the intentional killing of enemy combatants, but also the foreseeable but unintentional killing of enemy non-combatants and also of co-citizens to whom we owe a significant duty of care. Many have assumed that what fills this deficit is the non-vital interest of individual citizens in maintaining their independent self-determining state community. But if these interests play this role in the case of states, they must play the same role in the case of comparable non-state communities. This brings us directly back to the Cadbury problem.

\subsection{Conclusion}

For many thousands of years the proposition that politically ordered societies-notably states-have the right to defend their sovereign independence and territorial integrity through war has been a fixed point, a self-evident proposition that only cranks, eccentrics, or lunatics would question. But like many such fixed points in the history of ideas this proposition turns out to be false.

We are indeed living through a Copernican moment in international ethics. In the old paradigm, prevalent since the establishment of the Westphalian order, the rights and interests of individuals metaphorically 'orbited' those of the state-they were conceptually and normatively subordinated to the rights and interests of the state. But the human rights revolution inverts this order of priority. The individual human with attributes of freedom, rationality, and equality stands at the centre of the ethical universe. Political entities gain their normative status from the contributions they make to individual rights and welfare. The most profound objection to the traditional conception of national self-defence is that it permits, and often mandates, the mass wastage of individual rights in order to support the formal rights and status of political entities.

Where does this leave us? My conclusion is that coordinated, forceful defence against genocidal aggression can be morally justified in reductivist terms. ${ }^{33}$ But defence against political aggression, conducted through conditional threats, is morally problematic in both reductivist or analogical terms.

\footnotetext{
${ }^{32}$ Most Western states no longer conscript their citizens, but almost all have the legal capacity to do so.

${ }^{33}$ Though, as I suggested above, there are good reasons for denying that such acts of collective defence constitute acts of war.
} 


\section{DAVID RODIN}

Some might conclude (as traditional pacifists were long assumed to do) that we are obligated to simply surrender to or appease international political aggressors. But that conclusion is in no way warranted. International aggression, even in its non-genocidal, political form is a great evil that demands a robust and effective response. But a self-help regime centred on a presumptive right to conduct wars of self-defence is not that response. Instead, the considerations here introduced compel us to develop alternative ways to prevent and deflect conditional political aggression. In fact, history shows that we have an astonishing capacity to find social, institutional, and normative mechanisms that diminish or replace the role of violence in human affairs. ${ }^{34}$ It is here the focus of our analytical and political energy should be directed.

What we have, in fact, is a new normative position intermediate between just war theory and pacifism. It is not just war theory because within that theory defence against political aggression is not only permissible, it is paradigmatic. International law, for example, defines aggression almost entirely in political terms and does not reference human rights at all in the definition. ${ }^{35}$ But neither is this position a form of pacifism as traditionally conceived, because it permits coordinated, lethal, defensive violence against genocidal aggression. This new position-which have a viable (and perhaps the only viable) approach to the ethics of international violence.

\footnotetext{
${ }^{34}$ This is the argument made compellingly by Steven Pinker in The Better Angels of our Nature (London: Allan Lane, 2011).

${ }^{35}$ Though modern philosophical treatments like Larry May's do explicitly draw the connection to human rights Larry May, Aggression and Crimes Against Peace, (Cambridge: Cambridge University Press, 2008).
} 